\title{
Pelaksanaan Supervisi Akademik Kepala SMAN 1 Talamau
}

Oleh : 1.Hanifah Zakia, e-mail : hanifazakia86@gmail.com

2. Ririn Humaera, e-Mail : humaera.ririn@gmail.com

\begin{abstract}
Penelitian ini bertujuan untuk menggambarkan pelaksanaan supervisi akademik yang dilakukan oleh kepala sekolah SMAN 1 Talamau. Pendekatan dalam penelitian ini adalah pendekatan kualitatif dengan metode deskriptif. Popolasi dalam penelitian ini adalah seluruh guru yang mengajar di SMAN 1 Talamau. Penelitian ini menghasilkan gambaran nyata bahwa kepala sekolah sudah melaksanakan supervisi sesuai dengan apa yang seharusnya dilakukan oleh seorang supervisor. dari proses supervisi yang dilakukan kepala sekolah, dimana proses supervisi sudah berjalan sudah sesuai dengan apa yang seharusnya dilakukan oleh seorang kepala sekolah sebagai supervisor.
\end{abstract}

\section{Pendahuluan}

Salah satu masalah dalam dunia pendidikan adalah rendahnya kinerja guru. Nanang Fattah menegaskan bahwa kinerja diartikan sebagai ungkapan kemajuan yang didasari oleh pengetahuan, sikap dan motivasi dalam menghasilkan sesuatu pekerjaan (Fattah, 2001). Kinerja yang rendah akan berdampak pada penurunan mutu pendidikan dan menghambat tercapainya visi dari sekolah. Potret nyata guru di Indonesia saat ini masih jauh dari apa yang diharapkan. kinerja guru harus dikelola dengan baik dan dijaga agar tidak mengalami penurunan. Guru mempunyai tugas dalam mengantarkan tunas-tunas bangsa ke puncak cita- cita, untuk itu diperlukan guru yang memiliki kompetensi yang relevan dengan tugas dan tanggung jawabnya sebagai pengajar dan pendidik (Rifma, 2013). Bahkan, seharusnya selalu diperhatikan agar mengalami peningkatan secara terus-menerus (Barnawi dan Arifin, 2014).

Pertama, masih banyak guru bidang studi yang belum mampu mengimplementasikan perangkat pembelajaran yang telah dibuatnya dalam proses pembelajaran, bahkan masih ada yang belum mampu membuatnya. Kedua, masih banyak kita guru-guru yang belum mampu memanfaatkan kemajuan teknologi dalam kegiatan pembelajaran dan cenderung menggunakan metode konfensional yang menimbulkan rasa bosan bagi peserta didik. Ketiga, berdasarkan prototipe guru yang dibuat oleh Glickman, masih terdapat banyak guru bidang 
studi yang mempunyai motivasi rendah, hal ini berimplikasi pada proses pembelajaran yang berlangsung seadanya saja.

Menurut (Hadiyanto, 2014) guru mempunyai banyak peran. Untuk melaksanakan peranperan ini dengan baik, diperlukanlah sebuah pembinaan. Salah satu bentuk pembinaan terhadap guru tersebut ialah supervisi akademik. Supervisi akademik menurut Glicman bertujuan untuk yakni membantu guru dalam mengembangkan kemampuannya mencapai tujuan pembelajaran yang dicanangkan bagi murid-muridnya (Fathurrahman, 2015).

Dengan kata lain tujuan dari supervisi akademik adalah untuk membantu guru mencapai keprofesionalannya dalam pengajaran. Tidak hanya pada peningkatan pengetahuan dan keterampilan mengajar guru, melainkan juga pada peningkatan komitmen (commitmen) atau kemauan (willingness) atau motivasi (motivation) guru, sebab dengan meningkatkan kemampuan dan motivasi kerja guru, kualitas akademik akan meningkat.

Sabandi menyatakan bahwa seorang supervisor memegang peranan penting dalam meningkatkan kualitas guru agar dapat melaksanakan pembelajaran yang lebih berkualitas (Sabandi, 2013). Kepala sekolah sebagai supervisor mempunyai tanggung jawab untuk peningkatan kemampuan guru dalam mengelola kegiatan pembelajaran di sekolah serta mempunyai peranan yang sangat penting terhadap perkembangan dan kemajuan sekolah.

Supervisi akademik dilakukan guna meningkatkan profesional guru yang nantinya akan membawa ke arah kualitas output dan sekolah, serta kualitas pendidikan secara global. Untuk itu, upaya awal yang dilakukan dalam peningkatan mutu pendidikan adalah kinerja guru. Dengan demikian dapat ditegaskan bahwa peran kepala sekolah sebagai pemimpin pendidikan adalah membantu dan menfasilitasi guru dalam melakukan proses belajar mengajar dan melakukan penilaian menggunakan teknik-teknik supervisi secara tepat sehingga tercapai peningkatan kompetensi yang lebih baik.

Pelaksanaan Supervisi akedemik dilakukan dalam beberapa siklus, yaitu : Pemantauan, supervisi, pelaporan dan tindak lanjut. (Permendikbuud no.22 Tahun 2016).

1. Pemantauan : Proses pembelajaran dilakukan pada tahap perencanaan, pelaksanaan, dan penilaian hasil pembelajaran. Pemantauan dilakukan melalui antara lain, diskusi kelompok terfokus, pengamatan, pencatatan, perekaman, wawancara, dan dokumentasi. 
2. Supervisi : Supervisi proses pembelajaran dilakukan pada tahap perencanaan, pelaksanaan, dan penilaian hasil pembelajaran yang dilakukan melalui antara lain, pemberian contoh, diskusi, konsultasi, atau pelatihan pelaporan.

3. Hasil kegiatan pemantauan, supervisi, dan evaluasi proses pembelajaran. Ini semua disusun dalam bentuk laporan untuk kepentingan tindak lanjut pengembangan keprofesionalan pendidik secaraberkelanjutan.

4. Tindak Lanjut hasil pengawasan dilakukan dalam bentuk penguatan kepada guru yang menunjukkan kinerja yang memenuhi atau melampaui standar; dan pemberian kesempatan kepada guru untuk mengikuti program pengembangan keprofesionalan berkelanjutan.

\section{Metode Penelitian}

Penelitian ini mengunakan pendekatan kualitatif. penulisan penelitian ini bersifat deskriptif, yaitu memberikan gambaran suatu keadaan tertentu secara rinci disertai dengan bukti. Jadi penelitian ini bertujuan untuk mengetahui gambaran bagaimana pelaksanaan supervisi akademik kepala sekolah dalam meningkatkan kinerja guru bidang studi di SMA N 1 Talamau. Sampel dalam penelitian ini adalah guru-guru bidang studi dan kepala sekolah. Teknik pengumpulan data mengunakan teknik wawancara, observasi dan dakumentasi.

\section{Pembahasan}

1. Perencanaan Supervisi Akademik Oleh Kepala Sekolah Perencanaan supervisi akademik di SMAN 1 Talamau dilakukan untuk pada setiap semester dengan mempertimbangkan hasil evaluasi dari supervisi pada semester sebelumnya. Kepala sekolah menuatakan bahwa : penyusunan program supervisi akademik disesuaikan dengan standar proses yang sudah ditetapkan oleh pemerintah. Penyusunan program dimulai dari analisis supervisi di tahun sebelumnya. Dari hasil analisis kemudian membuat perencanaan supervisi

Dalam penyusunan program supervisi akademik kepala sekolah juga dibantu oleh wakil kepala sekolah bidang kurikulum. Perencanaan supervisi akademik tersebut diawali dengan pembentukan tim supervisor. Tim supervisi terdiri dari guru-guru 
senior yang dipilih sesuai dengan rumpun mata pelajaran yang ada. Untuk selanjutnya ditentukan jadwal pelaksanaan supervisi akademik.

2. Pelaksanaan Supervisi Akademik

Pelaksanaan program supervisi akademik akan berjalan dengan baik, apabila segala rencana yang telah disusun sudah dipersiapkan dengan baik, yakni dengan cara: a) Menerapkan prinsip supervisi: kontinyu, obyektif, konstruktif, humanistik dan kolaboratif. Pelaksanaan Supervisi akademik di SMAN 1 Talamau dilaksanakan secara terjadwal, yaitu satu kali dalam satu semester. Kepala sekolah menjelaskan : "supervisi akademik jadwalnya disusun bersama tim supervisor dan guru, dalam satu semester hanya satu kali.Kadang-kadang jadwalnya ada bergeser karena kesibukan kepala sekolah dan tim supervisor, akan tetapi hal itu bukan suatu masalah mengingat di dalam jadwal hanya mencantumkan hari.

Guru matematika menyatakan bahwa "supervisi juga mencatat hal- hal penting lainnya untuk pembinaan baik secara individu maupun bersama. Secara individu bila ada hal bersifat pribadi dan secara bersama-sama kalau itu bersifat umum

Dalam pelaksanaan supervisi akademik kepala sekolah menggunakan teknik yang berbeda-beda. Namun kebanyakan kepala sekolah menggunakan teknik supervisi individual dengan pendekatan secara langsung. Kepala sekolah mensupervisi guru secara individual dan langsung melakukan kunjungan kelas sesuai dengan kesepakatan yang telah dibuat.

3. Tindak Lanjut Supervisi Akademik

Di dalam kegiatan tindak lanjut diharapkan terjadi perubahan perilaku yang positif seorang guru yang pernah disupervisi. Perubahan- perubahan itu akan membawa seorang guru menjadi profesional dalam mengajar dan mutu pendidikan serta kinerjanya akan meningkat. Dalam hal tindak lanjut, kepala sekolah sudah melakukan dengan baik. Hal inibisa dilihat dari bukti dokumen mengenai pelatihan yang diikuti oleh para guru. Guru yang memiliki kendala dalam proses belajar mengajarnya yang ditemukan selama pelaksanaan supervisi diberikan pelatihan sesuai dengan kebutuhannya.

4. Evaluasi Supervisi Akademik 
Evaluasi dilakukan untuk mengetahui kelebihan dan kekurangan serta mencari penyebab terjadinya masalah untuk mencari solusi yang tepat mengenai program supervisi yang telah dilaksanakan dalam satu semester.

5. Laporan Supervisi Akademik

Laporan supervisi akademik dibuat setelah seluruh rangkaian kegiatan supervisi akademik selesai dilaksanakan. Kegiatan yang dimaksud adalah perencanaan, pelaksanaan, dan tindak lanjut dari supervisi akademik. Instrumen-instrumen yang digunakan dalam supervisi akademik selanjutnya dikumpulkan, direkap dan dihitung nilainya. "Jadi laporan supervisi akademik dibuat berdasarkan rencana program dan rekapan hasil dari instrumen. Konkritnya, laporan supervisi akademik memuat pendahuluan, deskripsi sekolah, tindakan supervisi, penutup, dan lampiran- lampiran".

\section{Simpulan dan Saran}

Dari hasil penelitian dapat disimpulkan bahwa siklus pelaksanaan supervisi akademik oleh kepala SMAN 1 Talamau telah terlaksana seusai dengan standar proses supervisi yang dikeluarkan oleh Menteri Pendidikan dan Kebudayaan nomor 22 Tahun 2016. Proses supervisi akademik berlangsung dengan baik mulai dari tahap perencanaan, pelaksanaan, evaluasi dan tindak lanjut.

Berdasarkan hasil kesimpulan dari hasil mini research yang dilakukan, maka berikut ini kami tuliskan beberapa saran terhadap pelaksanaan supervisi akademik kepala sekolah di SMA N 1 Talamau.

a Bagi kepala sekolah diharapkan agar dapat mempertahankan pelaksanaan supervisi akademik ini untuk meningkatkan kinerja guru disekolah.

b. Kepala sekolah diharapkan bisa meminimalisir faktor penghambat pelaksanaan supervisi seperti waktu pelaksanaan yang kadang-kadang molor dari yang sudah direncanakan.

c. Bagi sekolah agar dapat mempertahankan sistem pelaksanaan program supervisi, agar dalam pelaksanaannya ke depan lebih bagus lagi dan sesuai dengan tujuan diselenggarakannya program 


\section{Daftar Rujukan}

Nanang Fattah. (2001). Landasan Manajemen Pendidikan. Bandung: Remaja Rosdakarya.

Rifma. (2013). Problematika Kompetensi Paedagogik Guru Sekolah Dasar. 8.

Barnawi dan Mohammad Arifin. (2014). Kinerja Guru Profesional: Instrumen Pembinaan, Peningkatan dan Penilaian. Jogjakarta: AR-RUZZ MEDIA.

Hadiyanto. (2014). Mencari Sosok Desentralisasi Pendidikan. Rineka Cipta.

Muhammad Fathurrahman, H. R. (2015). Sukses Menjadi Supervisi Sekolah Ideal. Yogyakarta: Ar-Ruzz Media, 2015.

Sabandi, A. (2013). Supervisi Pendidikan Untuk Pengembangan Profesionalitas Guru Berkelanjutan. 8. 